УДК 630.8

\title{
ОСОБЕННОСТИ КАЧЕСТВЕННЫХ ХАРАКТЕРИСТИК ПРОДУКТОВ ПЕРЕРАБОТКИ ДРЕВЕСНОЙ ЗЕЛЕНИ ПИХТЫ СЕВЕРНЫХ РЕГИОНОВ
}

\author{
() C.O. Медведев ${ }^{\text {"* }}$, P.A. Степень ${ }^{2}$ \\ ${ }^{1}$ Лесосибирский фрилиал Сибирского государственного технологического \\ университета, ул. Победы, 29, Лесосибирск, 662543 (Россия), \\ e-mail: medvedev_serega@mail.ru \\ ${ }^{2}$ Сибирский государственный технологический университет, пр. Мира, 82, \\ Красноярск, 660049 (Россия)
}

В статье показано преимущество продуктов, получаемых из древесной зелени пихты северных регионов, в частности лесосибирского промышленного узла, в сравнении с лесостепными районами Сибири. Представлены качественные характеристики продуктов переработки древесной зелени пихты.

Ключевые слова: древесная зелень, пихта сибирская, экстракт, эфирное масло.

\section{Введение}

Древесная зелень пихты - ценный источник для получения большого количества продуктов. Известно, что ее состав и, следовательно, выход товарной продукции зависит от ряда биоценотических факторов. В связи с этим для объективной оценки ее объемов важно определить содержание в сырье экстрактивных веществ. Влияние индивидуальной, суточной, сезонной изменчивости мало зависит от географии и хорошо изучено на объектах сибирских лесов лесостепной зоны. Меньшая определенность - с возрастной и эндогенной изменчивостью содержания экстрактивных веществ ассимиляционного аппарата, в частности, исследуемой в настоящей работе пихты, которые коррелируют с географическим положением насаждений. Согласно данным Н.И. Шарапова [1], их вклад возрастает с продвижением к северным широтам. С учетом этого важно изучить влияние возраста деревьев и размещения древесной зелени в их кроне на содержание экстрактивных веществ и эфирного масла.

При рассмотрении способов утилизации древесной зелени пихты лесосибирского региона оценивались возможности ее утилизации посредством пихтоварения и экстрагирования углекислым газом и этиловым спиртом. Полученные данные сравнивали с результатами переработки этого сырья лесостепной зоны.

\section{Экспериментальная часть}

Отбор образцов осуществляли на промышленных лесозаготовительных участках. В каждом случае их отбирали с 15 нормально развитых деревьев (по две веточки с нижней, средней и верхней частей кроны молодняка, спелых и перестойных деревьев). Отбор осуществляли в сентябре - октябре, когда древесная зелень характеризуется максимальным содержанием и стабильным составом липидов и эфирных масел [2].

При подготовке образцов к экстрагированию и отгонке эфирного масла определяли влажность древесной зелени, проводили ее измельчение и осреднение. При постановке экспериментов проведено девять

Медведев Сергей Олегович - ассистент кафедры экономики и управления, e-mail: medvedev_serega@mail.ru

Степень Роберт Александрович - профессор кафедры промышленной экологии, процессов и аппаратов химических производств, доктор биологических наук серий опытов (3 возрастных группы $\times 3$ части кроны). Для достоверности получаемых данных в каждой серии опытов по определению выхода как липидов, так и эфирного масла эксперименты проводили в двукратной повторности.

\footnotetext{
* Автор, с которым следует вести переписку.
} 
При проведении исследований важно было оценить выход экстрактивных веществ и эфирного масла из древесной зелени лесосибирского региона, как нового сырья для получения продукции. Экстрактивные вещества из измельченной древесной зелени извлекали спирто-эфирной смесью в аппарате Сокслета. Продолжительность экстрагирования - 3 ч с закладкой 50 г сырья и объемом экстрагента 250 мл. Их выход определяли гравитометрическим путем.

Пихтовое эфирное масло из измельченной усредненной древесной зелени выделяли стандартным гидродистилляционным методом при атмосферном давлении в аппаратах Клевенджера. Выход определяли волюмометрически с учетом его растворения в кубовом остатке и пересчитывали на массу абс. сухого сырья. Состав эфирного масла анализировали методом ГЖХ на набивных колонках из нержавеющей стали $(2000 \times 3$ мм) с использованием неподвижной фазы SE-30 (5\%) на хроматоне и пламенно-ионизационном детекторе. Соотношение компонентов масла рассчитано методом внутренней нормализации. Для выявления возможной специфики в составе полученного продукта его сравнивали с эфирным маслом пихты, произрастающей в Красноярской лесостепи.

Анализировали также органолептические и физико-химические показатели лесосибирского пихтового масла $[2,3]$. При изучении его свойств определяли внешний вид, цвет, запах, плотность, кислотность, содержание борнилацетата. Первые три из них оценивали органолептически. Плотность находили пикнометрически, показатель преломления - рефрактометрически. Кислотность эфирного масла определяли титрованием, вклад борнилацетата - химическим и хроматографическим способами.

\section{Результаты и обсуждение}

Органолептические и физико-химические свойства пихтового масла среднеенисейской тайги практически не отличаются от таковых других регионов и выше стандартных показателей [2] (табл. 1).

При близких органолептических свойствах плотность и содержание борнилацетата в пихтовом масле лесосибирского региона выше, а кислотность - ниже, чем у высшего сорта стандартного продукта. Это означает, что он качественнее и дороже последнего и может обеспечить высокую прибыльность предприятия. Детальнее материалы по эфирному маслу пихты среднеенисейской тайги рассмотрены в следующем разделе.

С учетом предполагаемого строительства в Лесосибирске биохимического завода достаточно эффективным представляется этанольное экстрагирование древесной зелени. Тем более что в отличие от углекислотного в данном случае оно протекает при нормальном атмосферном давлении, и следовательно, упрощается оборудование и улучшается безопасность производства, что немаловажно для лесной территории.

Получение этанольного и $\mathrm{CO}_{2}$-экстрактов древесной зелени пихты среднеенисейской тайги в данной работе рассматривается лишь в общем виде, поскольку их реализация возможна лишь после запуска гидролизного предприятия. Промышленное и полупромышленное получение этих продуктов в России пока не реализовано. Последние из них вырабатываются из самого разного сырья, в том числе и небольшими партиями из хвойной древесной зелени, и потому стоят достаточно дорого. Укрупнение масштабов снизит их себестоимость и позволит использовать этот богатый биологически активными продуктами препарат во многих отраслях хозяйства.

Получаемый из древесной зелени лесосибирского региона $\mathrm{CO}_{2}$-экстракт - приятно пахнущая, с пихтовым оттенком масляная жидкость зеленовато-коричневого цвета. Его выход и физико-химические показатели и соответствующая характеристика данного продукта из пихты красноярской лесостепи [4] для сравнения приведены в таблице 2 .

Таблица 1. Основные показатели пихтового масла

\begin{tabular}{|c|c|c|c|c|}
\hline \multirow{3}{*}{ Показатель } & \multirow{3}{*}{ Лесосибирский регион } & \multicolumn{3}{|c|}{ Норма по ОСТ 13-221-86 для марки } \\
\hline & & \multicolumn{2}{|c|}{$\mathrm{A}$} & \multirow{2}{*}{ Б } \\
\hline & & Высший сорт & 1 copt & \\
\hline Внешний вид & $\begin{array}{c}\text { Зеленоватая прозрачная } \\
\text { маслянистая жидкость }\end{array}$ & \multicolumn{3}{|c|}{$\begin{array}{c}\text { Прозрачная жидкость без примесей воды и осад- } \\
\text { ков от бесцветного до светло-желтого или зеле- } \\
\text { новатого цвета }\end{array}$} \\
\hline Запах & Приятный смолистый & \multicolumn{3}{|c|}{$\begin{array}{c}\text { Характерный пихтовый без постороннего непри- } \\
\text { ятного оттенка }\end{array}$} \\
\hline 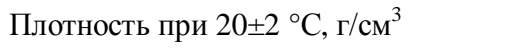 & 0,9042 & \multicolumn{3}{|c|}{0,894} \\
\hline Показатель преломления при $20 \pm 2{ }^{\circ} \mathrm{C}$ & 1,4668 & \multicolumn{3}{|c|}{$1,462-1,472$} \\
\hline Кислотное число, мг/г & 0,42 & 0,5 & 0,5 & 1,0 \\
\hline Массовая доля борнилацетата & 35 & 33 & 30 & 27 \\
\hline
\end{tabular}


Таблица 2. Выход и физико-химические показатели $\mathrm{CO}_{2}$-экстрактов пихты

\begin{tabular}{l|c|c}
\hline \multicolumn{1}{c|}{ Показатель } & Лесосибирский регион & Красноярская лесостепь [5] \\
\hline Выход, \% от а.с.с. & 5,7 & 5,0 \\
Плотность при $20 \pm 2{ }^{\circ} \mathrm{C}, \Gamma / \mathrm{cm}^{3}$ & 0,951 & 1,4925 \\
Показатель преломления, $n_{D}^{20}$ & 0,4981 & 30,07 \\
Кислотное число, мг/г & 37,3 & 58,04 \\
Эфирное число, мг $/ \Gamma$ & 60,3 & 53,55 \\
Содержание эфирного масла, \% от экстракта & 56,4 & 0,31 \\
Содержание воды в экстракте, \% & 0,4 & 45,70 \\
Содержание омыляемых веществ, \% от экстракта & 44,5 & 47,20 \\
Содержание неомыляемых веществ, \% от экстракта & 48,2 & \\
\hline
\end{tabular}

Сопоставление данных показывает, что при некотором различии выхода физико-химические показатели $\mathrm{CO}_{2}$-экстрактов практически одинаковы и могут одинаково применяться.

Выделенное из обоих препаратов эфирное масло также характеризуется близкими, хотя и более высокими показателями в случае северного региона (табл. 3)

Показатели эфирного масла, выделенного из сравниваемых экстрактов, отличаются несущественно, за исключением плотности продукта из сырья лесостепной зоны. Вероятно, приведено ошибочное значение. При плотности выше плотности воды $(1,000$ г/см³ $)$ нельзя выделять из препарата эфирное масло водяным паром. Судя по содержанию борнилацетата, его плотность должна быть около 0,884 г/ $\mathrm{cm}^{3}$.

Более эффективным экстрагентом считаются этанольные растворы. Они существенно больше, чем неполярные (бензин), но значительно меньше по сравнению с диэтиловым эфиром, посредством которого определяется содержание липидов, извлекают экстрактивные вещества из хвойной древесной зелени. При этом их выход заметно зависит от соотношения в охвоенных побегах хвои и побегов.

С учетом возможного строительства гидролизного завода в Лесосибирске и наличия больших объемов дешевого этилового спирта проведены опыты по экстрагированию этим растворителем древесной зелени пихтарников различного возраста. Результаты этанольного (40\%-го водного) экстрагирования усредненных образцов охвоенных побегов среднего яруса деревьев приведены в таблице 4.

Выход этанольных экстрактов из древесной зелени пихты исследуемых возрастных категорий превышает таковые липидов, что указывает на эффективность выработки данного продукта. Высокое содержание пигментов и других биологически активных соединений и экстрагирование легкоудаляемым из препаратов и нетоксичным в малых дозах растворителем делает благоприятным его использование в пищевых целях и в качестве кормовой добавки для животных.

Следует отметить его практически одинаковый вклад в охвоенных побегах пихты первых трех возрастов. В ходе дальнейшего развития его доля зачастую снижается: с 16,4\% в третьем до $11,0 \%$ в седьмом классе возраста.

Этанольный экстракт весьма богат пигментами, витаминами и другими биологически активными веществами. В нем содержатся также многие компоненты: сахара, аминокислоты и т.д. По своему составу он близок хлорофилло-каротиновой пасте. Их переработка, согласно специалистам СПбЛТА [6], значительно расширяет ассортимент продукции.

Таблица 3. Выход и физико-химические показатели эфирного масла $\mathrm{CO}_{2}$-экстрактов пихты

\begin{tabular}{l|c|c}
\hline \multicolumn{1}{c|}{ Показатель } & Лесосибирский регион & Красноярская лесостепь [5] \\
\hline Плотность при $20 \pm 2{ }^{\circ} \mathrm{C}, \Gamma / \mathrm{cm}^{3}$ & 0,8090 & 1,074 \\
Показатель преломления, $n_{D}^{20}$ & 1,4785 & 1,4775 \\
Кислотное число, мг/Г & 7,1 & 2,79 \\
Эфирное число, мг/Г & 75,4 & 59,81 \\
Борнилацетат, \% & 25,2 & 18,43 \\
\hline
\end{tabular}

Таблица 4. Выход этанольных продуктов древесной зелени пихты

\begin{tabular}{l|c|c|c|c|c}
\hline Возраст деревьев, лет & $15-20$ & $35-40$ & $50-60$ & $100-120$ & $130-150$ \\
\hline Выход экстракта, \% от а.с.с. & $16,8 \pm 0,5$ & $17,1 \pm 0,3$ & $16,4 \pm 0,7$ & $13,3 \pm 0,8$ & $11,0 \pm 0,6$ \\
\hline
\end{tabular}




\section{Выводы}

В результате исследования установлено преимущество продуктов, получаемых из древесной зелени пихты северных регионов, в частности лесосибирского промышленного узла, в сравнении с лесостепными районами Сибири. Полученные результаты имеют важное практическое значение для развития сети малых лесохимических предприятий на рассматриваемой территории, чему также в значительной степени будет способствовать организация биохимического производства, продукты которого (этиловый спирт и углекислота) могут быть использованы для получения из древесной зелени многих ценных продуктов.

\section{Список литературы}

1. Шарапов Н.И. Климат, продуктивность растений и качество эфирного масла. Л., 1969. 26 с.

2. Степень Р.А. Биохимия терпеноидов. Хвойные эфирные масла: свойства, получение, основные методы исследования, анализ. Красноярск, 1994. 36 с.

3. Ушанова В.М., Лебедева О.И., Девятловская А.Н. Основы научных исследований : Ч. 2. Контроль качества и экстрагирование растительного сырья. Красноярск, 2003. 168 с.

4. Лобанов В.В., Лобанова Е.Э., Степень Р.А. Комплексная переработка древесной зелени в условиях малого пихтоваренного производства. Красноярск, 2007. 144 с.

5. Ушанова В.Н., Ушанов С.В., Репях С.М. Состав и переработка древесной зелени и коры пихты сибирской. Красноярск, 2008. 257 с.

6. Юдкевич Ю.Д., Васильев С.Н., Ягодин В.И. Получение химических продуктов из древесных отходов. СПб., 2002. $84 \mathrm{c}$.

Поступило в редакичию 16 февраля 2012 2.

Medvedev S.O. , Stepen' R.A. FEATURES QUALITATIVE CHARACTERISTICS OF PRODUCTS PROCESSING WOOD GREENS OF A FIR NORTHERN REGIONS

${ }^{\text {I}}$ Siberian State Technological University (Lesosibirskiy branch), Pobedy st., 29, Lesosibirsk, 662543 (Росcия),

e-mail: medvedev_serega@mail.ru

${ }^{2}$ Siberian State Technological University, pr. Mira, 82, Krasnoyarsk, 660049 (Russia)

In the article advantage of the products received from wood greens of an Ábies sibírica of northern regions, in particular Lesosibirsk industrial region in comparison with forest-steppe areas of Siberia is shown. Qualitative characteristics of products of processing of wood greens of an Ábies sibírica are presented.

Keywords: wood greens, Ábies sibírica, extract, essence.

\section{References}

1. Sharapov N.I. Klimat, produktivnost' rastenii i kachestvo efirnogo masla. [Climate, plant productivity and quality of essential oil]. Leningrad, 1969, 26 p. (in Russ.).

2. Stepen' R.A. Biokhimiia terpenoidov. Khvoinye efirnye masla: svoistva, poluchenie, osnovnye metody issle-dovaniia, analiz. [Biochemistry of terpenoids. Coniferous essential oils: Properties, Production, the main methods of research and analysis.]. Krasnoyarsk, 1994, 36 p. (in Russ.).

3. Ushanova V.M., Lebedeva O.I., Deviatlovskaia A.N. Osnovy nauchnykh issledovanii : Ch. 2. Kontrol' kachestva i ekstragirovanie rastitel'nogo syria. [Basic research: Part 2. Quality control and extraction of plant raw materials.]. Krasnoyarsk, 2003, 168 p. (in Russ.).

4. Lobanov V.V., Lobanova E.E., Stepen' R.A. Kompleksnaia pererabotka drevesnoi zeleni v usloviiakh malogo pikhtovarennogo proizvodstva. [Complex processing of wood greens under small fir boiled production]. Krasnoyarsk, 2007, 144 p. (in Russ.).

5. Ushanova V.N., Ushanov S.V., Repiakh S.M. Sostav i pererabotka drevesnoi zeleni i kory pikhty sibirskoi. [Composition and processing of wood and greenery Siberian fir bark.]. Krasnoyarsk, 2008, 257 p. (in Russ.).

6. Iudkevich Iu.D., Vasil'ev S.N., Iagodin V.I. Poluchenie khimicheskikh produktov iz drevesnykh otkhodov. [Preparation of chemicals from wood waste.]. St. Petersburg, 2002, 84 p. (in Russ.).

\footnotetext{
* Corresponding author.
} 